\title{
LEGAL GUARANTEES ON PUBLIC CONTROL
}

\author{
Zhanna A. Kovalenko, \\ Kyiv National University of Trade and Economics, \\ Postgraduate student of the Department of Administrative, \\ Financial and Information Law, \\ 19 Kyoto Str., Kyiv, Ukraine, 02156 \\ https://orcid.org/0000-0002-5028-2400 \\ zhanna.kovalenko2018@knute.edu.ua
}

\begin{abstract}
Public control is an important mechanism for influencing upon public authorities. Its effectiveness ensures social participation within public administration indeed. The effectiveness of public control depends on the quality of its legal regulation and, in particular, upon perfection of mechanisms for public control.

Numerous shortcomings of the existing mechanisms for exercising public control are primarily considered due to the legal uncertainty of the guarantees on public control. After all, the guarantees on public control ensure proper functioning of the institution of public control and the effective implementation of the legal status of individuals in the field of public control and the entire social sphere in general. Without their comprehensive analysis, including clarification of its legal nature and essence, it is impossible to build, describe in detail and consolidate legislatively the system of guarantees on public control.

Within the frame of the study it has been found that the legal nature of the guarantees on public control and the specifications of their essence largely depend upon the kind of content that is embedded into the concept of the law. The author also believes that the most accurate way to reveal the nature of legal guarantees seems possible with the help of instrumental theory of law, namely being the key concept of "legal means". In this article the emphasis is stressed onto one of the main reasons for the existence of controversial points and differences in the understanding of legal guarantees, including public control, where there is the ambiguity for the basic category, i. e. "guarantee".

The article also formulates definitions of legal guarantees in the most general sense, as well as from the standpoint of instrumental theory of law. As a result, the author's understanding of legal guarantees on public control has been introduced.
\end{abstract}

Keywords: civil society, public authority, public administration, public control, legal guarantees.

\section{INTRODUCTION}

Social changes in Ukraine, in particular related to European integration processes, the development of civil society and the strengthening of democratic institutions have led to the transformation of relations between the state and the individual.

In order to implement the constitutional principle of guaranteeing human and civil rights and freedoms, public authorities have begun active involvement of the public not only into 
the decision-making process, but also in for creation of mechanisms that ensure direct participation of citizens within public administration (Shaulska, 2019). Just during the last few years, new forms of such a participation have been introduced in our country as follows: public councils, e-petitions, participation budget, public consultations, etc.

Being an integral part of the constitutional and legal status of human and citizen, public participation in public administration is one of the defining features of the civil society and legal democratic state. Ensuring for Ukraine of this participation is a means of achieving internal stability and one of the main conditions for full integration into European community.

Along with this, it should be noted that the main condition for the real participation of citizens in public administration is effective public control (Orel \& Smagliuk, 2018). Indeed, by promoting human and civil rights and freedoms and the interests of society in the whole, it's being an important mechanism for influencing authorities on all levels through the process of developing, adopting and implementing government decisions, as well as workout and embodiment of public policy (Gurzhii T., 2018).

Despite the importance of public control within the democratization of public institutions, the legal regulation of the relevant sphere of public relations is not of high quality. This is primarily due to the imperfection of existing mechanisms for public control. Insufficient regulation of the majority of legal procedures on the organization and implementation of public control creates just barriers to effective communication between civil society and the state (Ishchuk, 2018).

Numerous shortcomings of the public control mechanisms are primarily stipulated by the legislative unregulated guarantees on public control. After all, being general and important condition for the implementation of legal status of a person in relations with public authorities, the guarantees of public control create necessary and most favorable conditions for ensuring implementation, protection and defense of this right, as well as they increase the effectiveness of public control as mechanism for influencing public authorities.

Legal uncertainty of the guarantees on public control creates, first of all, problems in law enforcement: these are gross errors in the application of some rules of law, and the impossibility of implementing other ones. In addition, this unresolved issue makes it impossible to improve qualitatively legal regulation of the relevant sphere of relationships, including mechanisms for public control.

The situation is being further complicated by the fact that domestic scientists have not yet developed unanimous conceptual approach to defining the guarantees of public control phenomenon. Therefore, this in its turn complicates the process of building a system of the guarantees and their legislative consolidation.

At the same time, it should be noted that the legislative consolidation of guarantees of public control is to have positive impact upon the effectiveness of public participation in public administration, as well as on the stage of human rights and freedoms ensuring.

\section{LITERATURE REVIEW}

Many prominent lawyers have studied important aspects of public control, including its guarantees. In particular, I. O. Skvirsky investigated ideological basis for the institute of public control (Skvirsky, 2013). Guarantees of public control over the public administration's 
observance of human and civil rights and freedoms as one of the types of ensuring legality and discipline in public administration have become the subject of S. G. Stetsenko's consideration on this issue (Stetsenko, 2007). Legal guarantees of public control have found detailed enlightenment in 0. D. Tereshchuk's monograph "Administrative and legal principles of public control over law enforcement activities in Ukraine: theory and practice" (Tereshchuk, 2018). S. M. Khomov has been researching and considering juristic guarantees of public control over the activities of the SFS of Ukraine for a long period of time (Khomov, 2016). Instead, the issue of legal guarantees of public control, despite all its importance, remains out of the attention of domestic lawyers for many years in a row. The vast majority of these sphere researchers cover in their works just certain aspects of the problem, without resorting to comprehensive consideration of this unique phenomenon.

\section{RESULTS AND DISCUSSION}

The Constitution of Ukraine identifies the rights and freedoms of human and citizen, and their guarantees as a priority for the Ukrainian state. According to Part 2 of the Article 3 of the Basic Law, they determine the content and orientation of the state. The state is accountable before the personality for its activities, i. e. the establishment and the protection of human rights and freedoms is being fundamental duty of the state (Constitution of Ukraine, 1996).

One of these constitutionally proclaimed human rights is the right to participate in state affairs administration (Article 38 of the Constitution). In particular, the right of participation provides the opportunity to express and defend their views publicly, to promote effective solutions on solving problems of the society solely or in community with other citizens, to ensure consideration of common interests in the development, adoption and implementation of government decisions, to work out and implement state policy, to carry out control at all stages of cooperation with public authorities, to adjust the activities of the latter in accordance with the agreed positions (Dakhova, 2014).

The overall realization of the right to participate in management of public affairs depends on whether the community has effective mechanisms for influencing public authority (Karmaza, 2018).

Today, the community has a significant number of instruments to interact with public authorities and local governments: these are citizens' appeals, including electronic petitions, public consultations, public hearings, and participation in the work of advisory bodies to the executive authorities, etc.

Among these mechanisms, public control occupies important place. Being a derivative of the right to participate in administration of public affairs, the right of carrying out public control allows to identify violations of law, rights, freedoms and legitimate interests of individuals and legal entities; the interests of society, assess the consequences of those actions, and also to prosecute guilty persons to responsibility at all stages of the process of development; adoption and implementation of government managerial decisions, development and implementation of state policy. Therefore, just by carrying out of the control civil society acts as an equal partner of the state, and has the opportunity to "adjust" its activities in accordance with public interests. 
Legal regulation of relations in the field of organization and implementation of public control, which is the regulation of participants' behavior in public relations through legal means (Petryshyn, 2014, p. 134), finds its direct manifestation in the forms (sources) of law, being indispensable key to the stability of these relations and to the harmony of their development. The effectiveness of public control depends on the quality of legal regulation.

Despite all the value of public control, the right to carry it out is not constitutionally defined. In addition, there is no special legal act that regulates relations in the relevant sphere of activity. Instead, the great number of sectoral normative regulations declares the relevant law. Moreover, those few of them, which establish the mechanisms and forms of this right realization, often come into conflict with each other or some legislative acts, but regulate the relevant relations quite fragmentarily.

The unresolved number of issues in the field of organization and implementation of public control often leads to the fact that participation in public administration is just formal. Failure to take into account the interests of the society is the norm rather than the exception to the general rule. After all, insufficient regulation of the procedure for bringing public authorities and officials to justice allows the relevant actors to "ignore" public opinion (Gurzhii, 2020). One of those clear examples is the situation when public hearings are held, proposals based on their results are submitted, but local authorities not just delay the consideration of these proposals, but also do not consider them at all.

The same situation is concerning the settlement of the issue on public control guarantees. At the same time, it is quite obvious, that the formation of a proper legal basis and improvement of the existing one is impossible without guarantees of public control, their clearly constructed, detailed and legally established system. After all, the guarantees themselves are to ensure proper functioning of the relevant institution and effective implementation of the legal status of individuals in the field of public control and the public sphere in general (Mrówczyński, 2020).

Unfortunately, despite all the obviousness of this conclusion, nowadays the domestic legislator still cannot "boast" its conceptually holistic approach to understanding the guarantees on public control, including legal ones.

In our opinion, the development of conceptually holistic approach to understanding the legal guarantees on public control is possible only on the basis of comprehensive analysis of their nature and essence. Regarding this, comprehensive approach requires considering relevant guarantees from the standpoint of the basic concepts on legal understanding, which differently reveal the essence and social goals of law. After all, legal guarantees, as well as subjective law, legal obligation and legal responsibility are separate legal category, and therefore the legal nature of these guarantees, the specification of their essence largely depends on what meaning has been embedded into the concept of the law.

Almost the only scholar who has studied legal guarantees in terms of modern approaches to legal understanding is Professor E. V. Biloziorov. In particular, this scientist revealed the content, which is contributed into legal guarantees by the supporters of natural law concepts, positivism and sociological approach. He also made an attempt to determine the essence of the relevant guarantees in several aspects, namely in functional, instrumental, axiological, 
ideological, information-communicative, structural-substantive, social and cultural, and of course evolutionary one in the whole.

In particular, as E. V. Biloziorov noted, representatives of the naturally legal approach interpret legal guarantees through legal ideas, i. e. principles. For the positivists legal guarantees are means for establishing law and order in society. From the standpoint of the sociological approach, legal guarantees are socially conditioned phenomenon, i. e. factual relations reflected in the minds of people, within their interests, motives and goals, due to legal regulation subsequently reproduced through government authorities and public formations, and then within the activities of law-making bodies (Biloziorov, 2017, p. 23).

At the same time, within the frame of social and cultural aspect, legal guarantees, according to scholar's opinion, should be considered as social and cultural phenomenon, the main manifestations of which are legal culture and legal consciousness. In the functionalinstrumental aspect, the mutual influence of legal guarantees and other social spheres of life (politics, economics, religion) has been already determined; in the axiological aspect, legal guarantees is the category of great value; in the ideological one it's as an expression of a certain ideology (legal guarantees as a measure of freedom or some certain possibilities); in information and communication aspect, legal guarantees are an opportunity to receive and transmit information; in structural and substantive aspect, the features of legal guarantees, their content and nature has been revealed; in evolutional - it is origin, development and formation of legal guarantees.

As a result, E. V. Biloziorov emphasizes upon complexity and versatility of the concept of "legal guarantees". In his opinion, these guarantees are both a phenomenon of social reality and a legal phenomenon. At the same time, the scholar notes that the concept of legal guarantees is formulated within the social environment, where the features of the legal system, as well as the legal doctrine of the state is very important aspect in understanding for their essence (Biloziorov, 2017, p. 23).

Indeed, law is unique and multidimensional phenomenon, complex and polyhedral, social and polysemantic one, which determines the multifaceted nature of the phenomena determined by it, including legal guarantees of public control.

At the same time, along with the statement on importance of all existing concepts of legal understanding, it should be noted that the position of the legislator is to serve as "point of support" for the practical comprehension of legal guarantees on public control nature.

The legislator proceeds out from three aspects of understanding the law: general social (natural law), objective (positive law) and subjective.

Thus, general social law is an ascending element of such a social phenomenon like the law. It is the "foundation" for the development of objective law, as well as for subjective law either.

General social law arises long ago before the emergence of the state, and it exists independently of its own will. It has "accompanied" humanity since its inception, being reflection of human nature and inextricably linked to it. At the heart of this right, there are moral values and, above all, freedom and justice as the most essential goods in the conditions of public life. The initial form of existence of this right is the social consciousness. 
Manifestation of general social law are functionally different rights-opportunities (the right to life, the right to self-determination, the right to free use of natural objects, the right to property, the right to humane treatment of others, the right to freedom of creativity, the right to self-government, etc.), which ensures the very existence of a human. The content of these rights-opportunities is dynamic, and it depends on the level of social development. Natural law is not to be distributed (applied) onto relations of artificial origin, namely: relations arising in the field of human communities, which are connected to the state or exist in the form of state bodies (Nikolayeva \& Gurzhiy, 2021, pp. 42-49).

As T. 0. Gurzhiy righteously notes, "law in general social sense is the social awareness of the generally recognized, inherent inside human nature possibilities of a person abstractly taken through relations with other arbitrarily taken people; a set of natural human rights, which serve as a standard for the subsequent creation of legal norms, i. e. the regulations of subjective law “(Nikolayeva \& Gurzhiy, 2021, p. 46).

Objective law is epy part of objectively existing social environment. It exists independently of the will (desire) of an individual. Positive law acts as a product of the state (though not that way only) and functions within the country, or in the world, etc. Morality is not the predominant factor in the content of objective law. The initial form of positive law is a legal norm. Forms of expression for this right are normative legal acts, legal doctrine, legal custom, legal precedent, etc.

Traditionally, the objective law is considered as kind of social norms, in particular, as set of specific social norms (legal (juridical, or norms of law)). At the same time, norms of law are regulations established, recognized or sanctioned by the competent state body or by another general order; they are binding rules of conduct that regulate public relations in the interests of a human, citizen and society, and provide for the possibility of state coercive measures (including liability to the state) in case of their violation (Nikolayeva \& Gurzhiy, 2021, pp. 52-59). In general, objective law is the system of norms (rules of conduct or behavior) governing the possibility and the order of provision on human (person) needs, as well as satisfaction of his/her interests.

In its turn, subjective law is closely related to objective law: subjective law as it is being a dynamic manifestation of objective law. As a social value, subjective law is an opportunity, which is legally consolidated and guaranteed by society to satisfy a person, a citizen and other subjects of the law according to their needs and interests. As a juridical possibility, this law is the system of powers, which exists in the unity and for implementation of them. Among these powers are the following: the right to perform their own actions (active doings), which is the primary element of subjective law; the right to demand others' actions as the performance or observance of juridical obligation, i. e. the preconditions for legal opportunity realization; the right for protection by the state, i. e. the right that arises in case of violation of legal obligation, which is the obstacle on the implementation of subjective law (Nikolayeva \& Gurzhiy, 2021, pp. 60-62). For example, the right to education implies the obligation of the state to ensure the availability and free of charge education. Violation of this right is the cause for bringing the perpetrators to judicial liability.

Therefore, within the frames of general social understanding of the law, legal guarantees should be considered as phenomena of objective reality, due to the very nature of a human, 
the existence of which ensures implementation, protection and defense of human rights as the basis for freedom and justice. In the context of objective understanding of the law, legal guarantees or juridical guarantees should be considered as rules of law that meet the needs and interests of a person. At the same time, in the context of subjective understanding, they are taken up as separate elements (means) of the mechanism for legal regulation, which ensure implementation, protection and defense of legally consolidated capabilities of legal entities to meet their needs and interests.

It goes without saying, that in order to reflect all these aspects as for the definition of legal guarantees on public control is impractical, since it is to make it too "cumbersome" and unsuitable for scientific and practical use. Therefore, when making definition we try and limit ourselves to stating the legal nature of the guarantees on public control.

However, in our study we proceed from the fact that legal guarantees of public control are complex, multifaceted phenomenon, which covers both general conditions and certain means of the mechanism for legal regulation that ensure the implementation of legally consolidated rights for human, citizen and other subjects of law in order to meet their needs and interests.

Despite all the complexity and multilayered nature of such a phenomenon like the law, in our opinion, one of the main reasons for the discussion and differences in the understanding of legal guarantees, including public control, is the ambiguity of the basic category, that is "guarantee".

The concept of "guarantee" in reference literature is defined like the guarantee in something; conditions that ensure success in something; providing something; obligation provided by law or certain agreement, under which any person is liable to creditors in case of non-fulfillment of his/her obligations (Busel, 2005, p. 222); defending something (Melnichuk, 1982); third party liability for the debtor's obligations and/or the seller's or manufacturer's liability to the buyer for hidden defects of the product, that is valid for a certain period of time (Popovych, 2006). The above-mentioned ambiguity leads to differences in the understanding of guarantees by modern lawyers. In particular, O. F. Skakun defines legal guarantees as freedoms and responsibilities of person and citizen as the system of conditions, means and methods (social and economic, moral, political, legal) that ensure their actual implementation, defense and reliable protection (Skakun, 2001, p. 187). On the contrary to O. F. Skakun, N. M. Onishchenko and O. V. Zaychuk consider relevant guarantees as the system of norms, principles and requirements that ensure the process of human rights and legitimate interests observance (Zaychuk. \& Onishchenko, 2008, p. 105). Instead, K. Ya. Siokh believes that today these guarantees are any legal phenomena provided, on condition that they help to realize fundamental rights and freedoms of person and citizen, and to implement them into life (Siokh, 2018, p. 379).

In our opinion, such a situation does not contribute to the streamlining of the conceptual and categorical apparatus of legal science and the achievement of unity of views on the concept of "guarantees", including "legal guarantees".

To our opinion, it should be noted that any definition of guarantees and, in particular, legislative ("legal guarantees", "juridical guarantees", "guarantees of law", etc.) without any exception, should cover all aspects of its general comprehension. 
Thus, as an intermediate conclusion, we note that while defining the concept of "legal guarantees" and other related concepts, it is advisable to proceed from the fact that they provide the following: guarantee in something; conditions that ensure success in anything; securing something under a legal or contractual obligation; third party liability for the debtor's obligations, etc.

At the same time, it should be noted that legal guarantees are one of the manifestations of law, which is designed to ensure its effect and make enable the achievement of the social effect (purpose of legal regulation), which is planned by the legislator during the adoption of the law.

For these reasons, it seems that the most accurate way to reveal the nature of legal guarantees is possible with the help of instrumental theory of law, namely by its key concept of "legal means". After all, within the framework of this theory, law is considered as the system of legal means that while joining into certain mechanisms and modes, they are programming effective solutions to problems in social, economic, political and other spheres of society (Hanzenko, 2016, p. 38).

In the most general sense, according to 0 . V. Onufrienko, legal means are being the system of substantial and active legal phenomena that through the instrumental game help relevant subjects of legal relations to satisfy their private and public interests (Onufrienko, 2004, p. 15).

A. M. Denisova puts similar meaning into the concept of legal means. However, the scientist notes that substantial means are obligations, permits, prohibitions, incentives, benefits, rules of law, principles of law, etc.; and effective ones are the acts of law implementation, acts of law enforcement, acts of interpretation of law, as well as all processes of legal activity (Denisova, 2012, pp. 9-13).

At the same time, N. V. Zayats emphasizes that legal means are primarily the system of substantial phenomena of legal reality on different levels, which have a certain functional focus on solving social problems. In addition, the scholar notes that legal means can be considered in two aspects: legal (legal instruments and formalized results of the subjects' activity) and social (normative expression on the values of law, certain interests, etc.) ones (Zayats, 2016, p. 205).

It follows that legal means are directly related to the rules of law, as well as regulations, in which they find their expression. The necessary social effect is achieved only through the system of legal means. Instead, the phenomena of legal reality like law enforcement, rulemaking, other legal activities, including legal awareness, and legal culture are exclusively the manifestation of the application and use of legal means not being part of them.

Taking into account the above mentioned, legal guarantees can be defined as follows: legal means that ensure actual implementation, protection and defense of human rights and freedoms for citizens and other legal entities in order to satisfy their needs and interests that are consolidated into the regulation system.

Examining the issues of guarantees on public control, including legal ones, domestic legal scholars reveal some aspects of the relevant issues only.

For example, I. O. Skvirsky investigated a separate element of the system of guarantees on public control, namely the principles of community control. In particular, according to the scientist's opinion, this is the principle of construction and organization of public control 
that guarantee the existence of relevant legal institution; they lay necessary foundation for the functioning of public control and its further regulation. According to I. O. Skvirsky, the principle of the Supremacy of the Law occupies central place among the principles of public control. In particular, the author emphasizes upon the importance of the principles on hierarchical S Supremacy of the Law and public (state) governance, which are also important elements of the legal form of public control (Skvirsky, 2013, pp. 182-186).

From our side, we have to note that, despite the unconditional theoretical interest, I. O. Skvirsky's reasoning reveals only the ideological aspect of guarantees on public control, including legal ones, and it does not allow to formulate a holistic view onto this complex and multifaceted phenomenon.

O. D. Tereshchuk has defined the concept of legal guarantees on public control as follows. According to this scientist, legal guarantees on public control are systematic set of means, methods and conditions reflected in regulations adopted by authorized state bodies, which regulate and ensure activities of civil society institutions in this field by some other ways (subjects of public control), i. e. through active monitoring of these controlling entities, by public authorities and local governments activities in order to ensure implementation of legitimate rights and interests of certain persons, as well as mentioning their defense and protection (Tereshchuk, 2018, p. 176).

As for the legal guarantees being external form of expression of legal guarantees, the value of the scientific work of 0 . D. Tereshchuk for comprehensive understanding of the issue of guarantees on public control (including legal) is beyond doubt. At the same time, we consider it necessary to note that the definition of this researcher needs to be refined, since the activities of civil society institutions are not limited to observation. It may include inspections of controlled entities, public expertise, public consultations (Gurzhii, 2017), and other forms of public oversight.

In turn, S. G. Stetsenko distinguishes general guarantees of control over the observance by the public administration of human and civil rights and freedoms. The scientist understands them as the legal means that allow to observe activities of public administration in order to identify illegal decisions, actions or omissions (Stetsenko, 2007, p. 195).

The essence of the guarantees on public control, according to S. G. Stetsenko, is not directly disclosed. However, bearing in mind that the scholar puts the general guarantees on control over the observance by the public administration of human and civil rights and freedoms onto the public; his scientific conclusions relate to one aspect of the issues of guarantees on public control. At the same time, the debatable points of the definition on general guarantees of control proposed by S. G. Stetsenko are as follows: reduction of subjects' activity of public control exclusively to observation, although, as we have already mentioned, there are other forms of such an activity; identification of the purpose of public control and the purpose of guarantees on public control.

The question of the purpose of guarantees on public control needs some clarification. This is primarily because the meaning of the terms "purpose of public control" and "purpose of guarantees on public control" to some extent overlaps, however, it is not identical. We have already noted about the purpose of public control as a key feature of community control, exploring legal nature of public control. In particular, we have established that the 
purpose of public control is, firstly, the results obtained as circumstances of public control subjects' activities, namely the performance of certain tasks of this control. Developing the conclusions proposed above, we are going to try and define the purpose of guarantees on public control more clearly.

Thus, the functional outcomes of public control should be considered as full public participation in public administration, improving the efficiency of public authorities, promoting the formation of civil society in Ukraine, building partnership between state and society. The relevant results and tasks of public control that mediate them are nothing but the needs and interests of the subjects of public control. Basing on these considerations, we consider that the result of the function (purpose) of the guarantees on public control is primarily to ensure the right to exercise public control.

S. M. Khomov was one of the few scholars who attempted to define the concept of legal guarantees on public control. However, public control is considered by this scientist at a purely institutional level (namely, at the level of the SFS operating in Ukraine), which could not but leave a "scar" on the author's definition. Thus, according to S. M. Khomov, legal guarantees on public control are the system of legal means by which rights and obligations of public control subjects and SFS of Ukraine are consolidated; the conditions for their realization and exercising public control over the activities of this service in this sphere are created. At the same time, the researcher refers to the guarantees as to forms of public control, in particular public hearings, public expertise, and public participation in the work of collegial bodies at public authorities (Khomov, 2016, p. 123).

In general, while positively evaluating S. M. Khomov's attempt to define the concept of legal guarantees (the definition traces the connection between rights and obligations), it should be noted that the definition proposed by him is debatable. This is primarily because the author levels together concepts like the means with the forms. This identification is incorrect, because the relevant concepts do not coincide in scope. In particular, we adhere to an approach in which legal forms are correlated with legal means as the part and the whole thing (Zayats, 2016).

The analysis of scientific and legal research in the field of legal guarantees on public control gives grounds to assert that today there is no clear and unambiguous understanding of the essence of legal guarantees on public control. As a rule, domestic scholars consider such guarantees only in the context of general issues on public control, without resorting to their thorough analysis. The same individual researchers who try to give at least a general description of the relevant guarantees or identify them with legal guarantees, or consider public control in a functional aspect only (i. e. in the meaning of organizational and legal institution or mechanism). Instead, guarantees on public control as human rights are ignored.

\section{CONCLUSIONS}

Taking into account the above mentioned, as well as when basing on the dualistic essence of public control as human rights, organizational and legal mechanism for its implementation, the concept of legal guarantees on public control can be defined as follows: the regulation system of means that ensures real implementation, protection and defense of the right to 
carry out public control, consolidated in normative and legal acts, in order to form civil society, social participation in public administration, increase the efficiency of public authorities, as well as building up partnership between state and society.

\section{REFERENCES}

Beloziorov E. V. (2017). Legal Guarantees: Modern Approaches to Juidical Understanding: Proceedings of the 2017 Conference "Law Enforcement: History, Current Status, Prospects (pp. 22-24). Kiev, Ukraine: National Academy of Internal Affairs of Ukraine.

Busel V. T. (2005). Reference Dictionary of Modern Ukrainian Language 250,000 (VIII). Kiev: Perun, 1728 p. Dakhova I. I. (2014). Citizen Participation in Administration of Public Affairs: Questions of Theory and Practice. Forum of Law, 3. pp. 102-109. Retrieved from: http://nbuv.gov.ua/UJRN/FP_index.htm_2014_3_18. Denisova A. M. (2012). Mechanisms and Means of Legal Influence (Theoretical and Legal Research). PhD Dissertation. Kiev: National Academy of Internal Affairs of the Ministry of Internal Affairs of Ukraine, $230 \mathrm{p}$. Gurzhii T., Goncharuk S., Kuzmenko O., Berlach A., Yarmaki K. (2020). Establishment of the Institute of Administrative Responsibility in the Legal System of Ukraine. Journal of Law and Political Sciences, 2/C, 235-260.

Gurzhii T., Gurzhii A., Seliukov V. (2018). Public Administration of Personal Data Protection in Modern Ukraine. Politické vedy, 21 (2), 138-15.

Gurzhii T. (2017). Public Consultations in Ukraine: Topical Legal Issues. Rocznik Administracji Publicznej, 3, 309-318.

Hanzenko 0. O. (2016). Theory of Legal Means in the Context of Instrumental theory of Law. Bulletin of Zaporizhia National University, 3. pp. 36-42. Retrieved from: http://nbuv.gov.ua/UJRN/Vznu_Jur_2016_3_7. Ishchuk, S. (2018). Selected Problem Aspects of the Implementation of Public Control in Ukraine. ScienceRise: Juridical Science, 4 (6). pp. 15-19. https://doi.org/10.15587/2523-4153.2018.153482. Karmaza O. O., Sarana S. V., Fedorenko T. V., Gurzhii T. O., Nefedova A. V. (2018). The Protection of Civil Rights and Interests in the Court. Journal of Advanced Research in Law and Economics, 9(8), 262-263.

Khomov S. M. (2016). Administrative and Legal Principles of Public Control over the Activities of the State Fiscal Service of Ukraine. PhD Dissertation. Kyiv: National University of Life and Environmental Sciences of Ukraine, $201 \mathrm{p}$.

Konstytutsiia Ukrainy. Data onovlennia 01.01.2020. Retrieved from: https://zakon.rada.gov.ua/laws/ show/254\%D0\%BA/96-\%D0\%B2\%D1\%80\#Text.

Melnichuk O. S. (1982). Etymological Dictionary of the Ukrainian language: In 7 vols. Vol. 1: AG. Retrieved from http://surl.li/znpa.

Mrówczyński M., Knepka T., Hurzhii T., Gurzhii A. (2020). Prawo publiczne wobec aktualnych problemów społecznych i gospodarczych. Poland: Bydgoszcz, 312.

Nikolaeva L. V., Gurzhiy T. O. (2021). Theory of State and Law: Textbook. Kyiv: Kyiv National University of Trade and Economics, $424 \mathrm{p}$.

Onufrienko O. V. (2004). Legal Means in the Context of Instrumental Theory of Law. PhD Thesis. Kharkiv: National University of Internal Affairs, $18 \mathrm{p}$.

Orel Yu. L., Smaglyuk A. A. (2018, April). Civic Participation and Public Control as a Mechanism for Improving the Quality of Public Services in Ukraine: Proceedings of the XVIII Conference "International Science Congress of Public Administration of the XXI Century: World Practices and National Perspectives" (pp.82-85). Kharkiv, Ukraine: HarRI NAPA Publishing House "Master".

Petryshyn O. V., Pogrebnyak S. P., Smorodynsky V. S. (2014). Theory of State and Law: Textbook for Students. jurid. higher ed. est. textbook. Kharkiv: Law, 368 p. 
Popovich M. V. (2006). Universal Dictionary-Encyclopedia (4 $4^{\text {th }}$ ed.). Lviv: TEKA, 1432 p. Retrieved from: http://surl.li/znqj.

Shaulskaya G. M. (2019). Some Modern Mechanisms of Cooperation Between Government and Civil Society in Ukraine: Efficiency Analysis. Scientific Notes of the Institute of Legislation of the Verkhovna Rada of Ukraine, 2. https://doi.org/10.32886/instzak.2019.02.19.

Siokh K. Ya. (2018). Legal Gguarantees of the Constitutional Right of Citizens of Ukraine to Civil Service in the Conditions of Modern Reforms. Retrieved from: https://scholar.google.com.ua/ citations?user=PvdVc4UAAAAJ\&hl=ru.

Skakun O. F. (2001). Theory of the State and Law: Textbook. Kharkiv: Consumption, 656 p.

Skvirsky I. O. (2013). Public Control in Public Administration: Theoretical, Legal and Praxeological Aspects. PhD Dissertation. Zaporizhia: Zaporizhia National University, 413 p.

Stetsenko S. G. (2007). Administrative Law of Ukraine: Textbook. Kiev: Attica, 624 p.

Tereshchuk O. D. (2018). Administrative and Legal Principles of Public Control over Theelaw Enforcement in Ukraine: Theory and Practice: Monograph. Kyiv: SE "Ed. house "Staff", 460 p.

Zayats N. V. (2016). Essential Charcteristic of Legal Means in the Mechanism of Legal Regulation. Entrepreneurship, Economy and Law, 12. pp. 202-205. Retrieved from: http://nbuv.gov.ua/UJRN/ Pgip_2016_12_38.

Zaychuk O. V., Onishchenko N. M. (2008). Theory of State and Law: Textbook, $2^{\text {nd }}$ ed., Revised. and ext. Kiev: Jurinkom Inter, 688 p. 